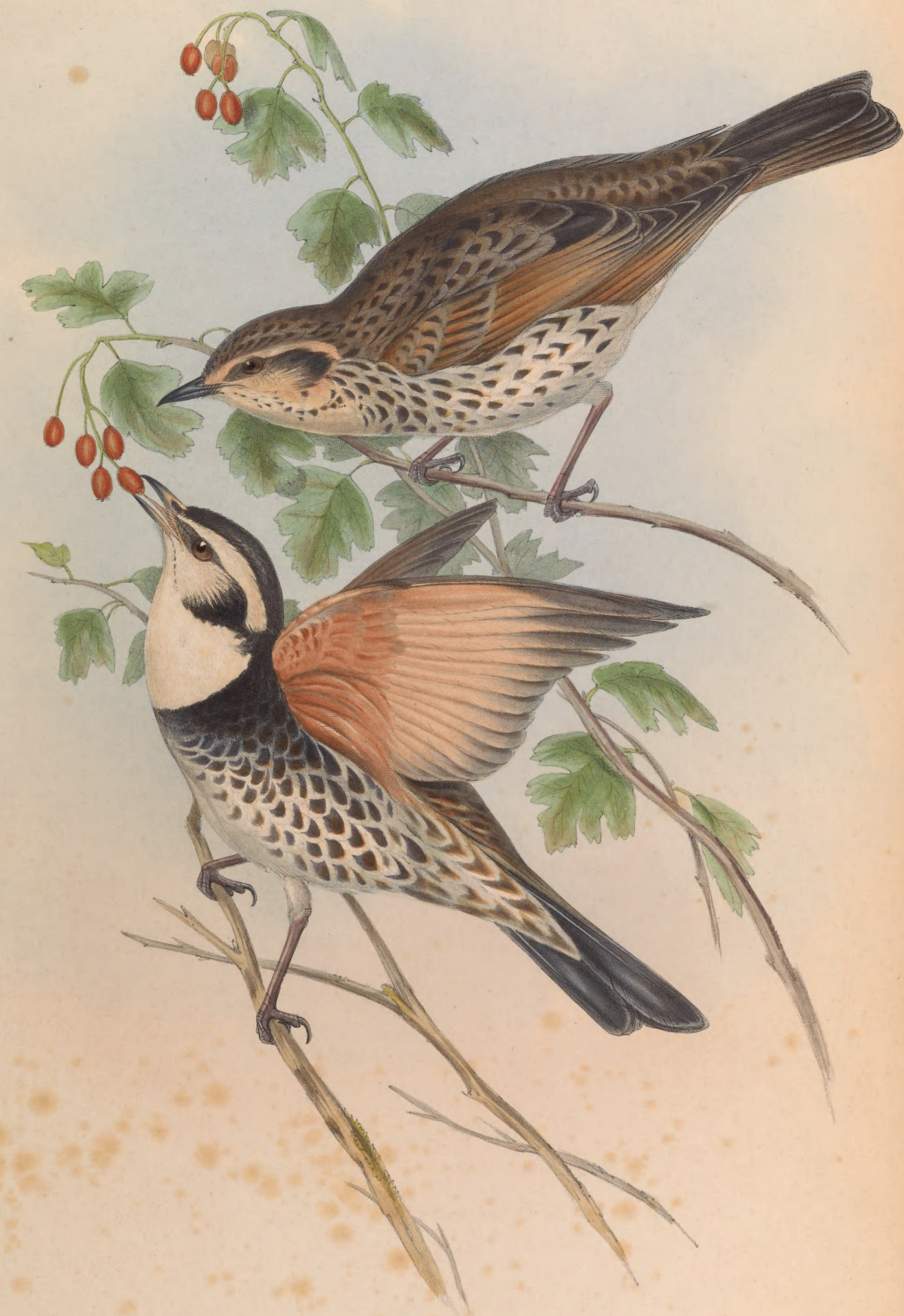




\section{TURDUS FUSCATUS, Pall.}

\section{Clouded Thrush.}

Turdus fuscatus, Pall. Zoog., tom. i. p. 451. pl. xii.

dubius, Naum. Vög. Nacht., Edit. i. Add. p. 22. pl. 4. f. 8. tom. ii. p. 288. pl. 68. figs. 1 \& 2.

Naumanni, Temm. Man. d’Orn., tom. i. p. 170 ; tom. iii. p. 96.-Brehm, Vög. Deutsch., p. 391.-Naum. Vög. Nacht., 2nd Edit. tom. xiii. pl. 358. figs. 2 \& 3 (according to M. Middendorff).-Gould, Birds of Europe, vol. ii. pl. 79.-Gray and Mitch. Gen. of Birds, vol. i. p. 219, Turdus, sp. 19.-Cat. of Spec. and Draw. of Mamm. and Birds presented to Brit. Mus. by B. H. Hodgson, Esq., p. 80.-Temm. et Schlegel, Fauna Japonica, p. 61.-Bonap. Consp. Gen. Av. p. 270, Turdus, sp. 6.

- eunomus, Temm. Pl. Col., 514.-Bonap. Consp. Gen. Av., p. 270, Turdus, sp. 7.

ThE present bird is very widely dispersed over Siberia, the northern parts of China, and the island of Japan; solitary individuals have been taken in various parts of Germany, and from its wandering habits it is very probable that its range will not be confined within these limits, and that it will some day or other be included in the list of the Fauna of the British Islands. As is the case with many others of the RussoAsiatic birds, much confusion exists with respect to its synonymy; some writers being of opinion that the Turdus dubius of Naumann and the Turdus dubius of Bechstein both have reference to it; but M. Temminck distinctly states that the latter name has been given to one of the stages of plumage of Turdus atrogularis ; and in order to prevent any confusion arising from the ambiguous term dubius, he has given it the name of Naumanni, by which it is now generally known; it is certain, however, that the bird was discovered by Pallas in the last century, and accurately described by him in his 'Zoographia Rosso-Asiatica' under the name of Turdus fuscatus, a term which, in justice to this great traveller and naturalist, I have felt it only right to retain.

“To judge from the great number of specimens killed in Japan by the Dutch naturalists," say MM. Temminck and Schlegel in their recently published and valuable 'Fauna Japonica,' " this bird appears to be very abundant in that country; Pallas states that he met with it in the alpine forests of Dauuria, that it has been observed by Gmelin and Messerschmidt on the borders of the rivers Selinga, Tongooska and Jenisséi, and that Bellings and Merk brought skins from Kamtschatka and the neighbouring islands. Besides a specimen taken at Anhalt Köthen, Naumann mentions many others killed in Silesia and in the neighbourhood of Vienna; but its appearance in Europe can only be considered accidental." Mr. Hodgson states that this species is very rare in the Himalayas, and that examples have been collected at Chusan by Dr. Playfair.

The male has the head and upper surface very dark brown, each feather broadly margined with pale greyish brown, with a tinge of red next the darker colour; wing-coverts, secondaries and primaries very dark brown, broadly margined externally with rufous, passing into greyish brown at the tip ; under surface of the wing rufous; a broad stripe over the eye; cheeks, chin and throat buffy white; lores and ear-coverts brownish black; feathers of the flanks brownish black edged with greyish white, the grey margins becoming larger and more conspicuous as the feathers proceed towards the vent; abdomen white; under tail-coverts dark reddish brown largely margined with white; tail very dark brown, edged externally at the base with rufous; bill olive-yellow, passing into black at the tip ; feet dark flesh-colour.

The female is similar in colour to the male, except that the superciliary stripe and the throat are more buff, that on each side of the throat there is a series of small, nearly triangular black marks, and that the colouring of the throat and flanks gradually blends instead of being separated by a distinct line of demarcation.

The Plate represents both sexes of the natural size. 


\section{$2 \mathrm{BHL}$ Biodiversity Heritage Library}

Gould, John. 1852. "Clouded Thrush, Turdus fuscatus, Pall. [PI. 1]." The Birds of Asia 3(IV), -. https://doi.org/10.5962/p.323184.

View This Item Online: https://www.biodiversitylibrary.org/item/118635

DOI: https://doi.org/10.5962/p.323184

Permalink: https://www.biodiversitylibrary.org/partpdf/323184

\section{Holding Institution}

Smithsonian Libraries

\section{Sponsored by}

Smithsonian Institution Libraries

\section{Copyright \& Reuse}

Copyright Status: Not in copyright

This document was created from content at the Biodiversity Heritage Library, the world's largest open access digital library for biodiversity literature and archives. Visit BHL at https://www.biodiversitylibrary.org. 